\title{
CYBER COUNSELING SEBAGAI SALAH SATU MODEL PERKEMBANGAN KONSELING BAGI GENERASI MILENIAL
}

\author{
DYAH LUTHFIA KIRANA \\ Fakultas Dakwah dan Ilmu Komunikasi UIN Mataram \\ Email: dyluki@yahoo.co.id
}

\begin{abstract}
The development of technology and communication provides convenience and extends the space for the movement of society today. Most of the activities of society are no longer limited by space and time, anytime and anywhere. The use of social media is high in proportion to the development of millennial generation who are familiar with technology. This generation has the characteristics of open communication, fanatical social media users, their lives are greatly affected by technological developments. Professional counselors must create a creative and innovative ways, strategies or methods to support guidance and counseling services for the millennial generation. Cyber Counseling is a services form of innovation and breakthrough in the world of counseling for millennials. Some Cyber Counseling methods that have been used by counselors include: E-mail-based Cyber-counseling, Android-based CyberCounseling Chat, Text-Based Cyber Counseling Using Riliv Android Applications, and Facebook-based Cyber Counseling.
\end{abstract}

Keywords: Technology, Cybercounseling, Counselors, Millennials

Abstrak: Adanya perkembangan teknologi dan komunikasi memberi kemudahan dan memperluas ruang gerak masyarakat dewasa ini. Artinya hampir sebagian besar aktivitas masyarakat tidak lagi dibatasi oleh ruang dan waktu, kapan dan dimana saja. Penggunaan media social yang tingoi sebanding dengan perkembangan generasi milenial yang sangat akrab dengan teknologi. Generasi ini mempunyai karakteristik komunikasi yang terbuka, pengguna media sosial yang fanatik, kehidupannya sangat terpengaruh dengan perkembangan teknologi. Konselor yang professional harus menciptakan cara, strategi atau metode baru yang kreatif dan inovatif untuk menunjang pelayanan bimbingan dan konseling pada generasi milenial. Pelayanan cybercounseling adalah salah satu bentuk inovasi dan terobosan dalam dunia konseling bagi generasi milenial. Beberapa metode cyber counseling yang telah digunakan oleh konselor, antara lain: CyberCounseling berbasis 
E-mail, Cyber counseling Chat-Asynchonous berbasis android, Cyber Counseling Berbasis Teks Menggunakan Riliv Aplikasi Android, dan Cyber Counseling berbasis Facebook.

Kata Kunci: Teknologi, Cybercounseling, Konselor, Generasi Milenial

\section{A. Pendahuluan}

Seiring dengan perkembangan teknologi informasi yang berkembang sangat pesat dimana pada masa sekarang ini dikenal dengan era reformasi industri 4.0 yang menyebabkan perkembangan teknologi informasi mulai dari smartphone hingga media sosial telah mengubah gaya hidup masyarakat. Menurut McLuhan ${ }^{1}$ "inovasi dalam bidang teknologi informasi atau teknologi komunikasi memberi perubahan yang sangat besar terhadap kehidupan masyarakat”. Kehidupan masyarakat saat ini memanfaatkan kecanggihan teknologi media online dalam pencarian informasi, sehingga informasi dapat diperoleh dengan cepat dan mudah.

Kecanggihan teknologi melalui media online menyebabkan setiap aktivitas manusia di seluruh dunia mampu dijangkau melalui media sosial,

"Nakhma'ussolikhah, “Studi Tentang
Penggunaan Cybercounseling Untuk Layanan Konseling
Individual Bersama Mahasiswa Program Studi Bimbingan
Dan Konseling Unu Cirebon" Oasis : Jurnal Ilmiah Kajian
Islam. Vol. 2. No. 1, 2017, hal. 3.
Islam. Vol. 2. No. 1, 2017, hal. 3. seperti instagram, facebook, twitter, dan lain sebagainya.

Penggunaan media sosial tersebut tanpa adanya batas-batas ruang, biaya, waktu, usia, suku, budaya, dan agama ${ }^{2}$. Penggunaan media social yang tinggi sangat sebanding dengan generasi milenial yang berkembang pada era revolusi industri 4.0 pada masa sekarang ini. Generasi milenial menurut Elwood Carlson dalam ukunya yang berjudul The Lucky Few: Between the Greatest Generation and the Baby Boom (2008), generasi milenial adalah mereka yang lahir dalam rentang tahun 1983 sampai dengan 2001. Jika didasarkan pada Generation Theory yang dicetuskan oleh Karl Mannheim pada tahun 1923, generasi milenial adalah generasi yang lahir pada rasio tahun 1980 sampai dengan 2000. Generasi milenial juga disebut sebagai generasi $\mathrm{Y}^{3}$. Salah satu ciri utama

${ }^{2}$ Sutijono \& Farid, Cyber Counseling Di Era Generasi Milenial. Jurnal Pendidikan Sains Sosial Dan Kemanusiaan. Vol. 11. No.1, 2018, hal. 20.

${ }^{3}$ Badan Pusat Statistik, Statistik Gender Tematik: Profil Generasi Millenial, (Jakarta: KemenPPA, 2018), hal. 14. 
al-Tazkiah, Volume 8 No. 1, Juni 2019

generasi milenial ditandai oleh merupakan salah satu alternative peningkatan penggunaan dan keakraban konseling yang sangat tepat sebagai dengan komunikasi, media, dan model konseling pada masa sekarang ${ }^{6}$. teknologi digital ${ }^{4}$. Generasi ini Pelaksanaan konseling yang sudah lazim merupakan generasi yang melibatkan dilakukan adalah dengan tatap muka teknologi dalam segala aspek kehidupan. langsung antara konselor dengan Bukti nyata yang dapat diamati adalah konseli, namun sejalan dengan pesatnya hampir seluruh individu dalam generasi tersebut memilih menggunakan ponsel perkembangan teknologi proses konseling hadir dengan metode yang pintar atau smartphone. Dari perangkat tersebut mereka mampu melakukan apapun dari sekadar berkirim pesan singkat, mengakses situs pendidikan, bertransaksi bisnis online, hingga memesan jasa transportasi online.

Generasi ini mempunyai berbeda, itu artinya proses konseling tidak hanya dimaknai sebagai pertemuan tatap muka (face to face) antara konselor dengan konseli yang dilakukan di ruangan, namun lebih dari itu konseling dapat dilakukan dengan karakteristik komunikasi yang terbuka, teknologi yang dihubungkan oleh pengguna media sosial yang fanatik, jaringan internet, yang dikenal dengan kehidupannya sangat terpengaruh dengan perkembangan teknologi, serta lebih terbuka dengan pandangan politik dan ekonomi ${ }^{5}$.

Melihat begitu pesatnya istilah e-konseling, atau cyber counseling atau dikenal juga dengan istilah virtual konseling $^{7}$. Proses konseling dapat diselenggarakan dengan berbagai media yang memungkinkan hubungan perkembangan teknologi informasi pada konseling jarak jauh ${ }^{8}$.

saat ini dan begitu lekatnya generasi milenial dengan teknologi, konselor sebagai salah satu profesi professional harus mengembangkan keilmuan sesuai dengan perkembangan teknologi dan informasi tersebut. Cyber counseling

${ }^{6}$ Pasmawati, H, Cyber Counseling Sebagai Metode Pengembangan Layanan Konseling Di Era Global. Jurnal Syi'ar. Vol. 16 No. 1. 2016, hal. 43.

${ }^{7}$ Ifdil, Pelayanan e-Konseling Pengolahan Hasil Pengadministrasian Alat Ungkap Masalah (AUM) dengan Menggunakan Program Aplikasi. Paper Persented at the Seminar Internasional Bimbingan dan Konseling Dalam rangka Kongres XI dan Konvensi Nasional XVI ABKIN. 2009, hal. 3.

${ }^{8}$ Pasmawati, H. Cyber Counseling Sebagai Metode Pengembangan Layanan Konseling Di Era Global. Jurnal Syi'ar. Vol. 16 No. 1. 2016, hal. 43. 


\section{B. Metode Penelitian}

Elwood Carlson dalam bukunya yang berjudul The Lucky Few: Between the Greatest Generation and the Baby Boom (2008), generasi milenial adalah mereka yang lahir dalam rentang tahun 1983 sampai dengan 2001. Jika didasarkan pada Generation Theory yang dicetuskan oleh Karl Mannheim pada tahun 1923, generasi milenial adalah generasi yang lahir pada rasio tahun 1980 sampai dengan 2000. Generasi milenial juga disebut sebagai generasi Y. Istilah ini mulai dikenal dan dipakai pada editorial Koran besar Amerika Serikat pada Agustus 1993․

Putra (2016) dalam kajiannya tentang teori perbedaan generasi menyajikan pengelompokan generasi (salah satunya adalah generasi milenial) dari beberapa pendapat peneliti yang berasal dari berbagai negara. Ada 6 (enam) pendapat tentang generasi milienial yang dilihat dari rentang waktu kelahiran ${ }^{10}$.

Penyebutan istilah generasi milenial juga berbeda antar peneliti. Tapscott (1998) menyebut generasi milenial dengan istilah Digital Generation

\footnotetext{
${ }^{9}$ Badan Pusat Statistik, Statistik Gender Tematik: Profil Generasi Millenial, (Jakarta: KemenPPA, 2018), hal. 14.

${ }^{10}$ Ibid., hal. 15.
}

yang lahir antara tahun 1976-2000. Kemudian Zemke et al (2000) menyebut generasi milenial dengan istilah Nexters yang lahir tahun 1980-1999. Oblinger (2005) menyebut generasi milenial dengan istilah Generasi Y/NetGen, lahir antara 1981-1995. Terakhir Howe dan Strauss, Lancaster dan Stillman (2002), serta Martin dan Tulgan (2002) menyebut dengan istilah Generasi Milenial/ Generasi Y/Milenial yang dikenal sampai sekarang, meskipun rentang tahun kelahirannya masingmasing berbeda ${ }^{11}$.

\section{Ciri-ciri Generasi Milenial}

Generasi milenial memiliki karakter unik berdasarkan wilayah dan kondisi sosial-ekonomi. Salah satu ciri utama generasi milenial ditandai oleh peningkatan penggunaan dan keakraban dengan komunikasi, media, dan teknologi digital. Karena dibesarkan oleh kemajuan teknologi, generasi milenial memiliki ciri-ciri kreatif, informatif, mempunyai passion dan produktif $^{12}$. Dibandingkan generasi sebelumnya, mereka lebih berteman baik dengan teknologi. Generasi ini merupakan generasi yang melibatkan

\footnotetext{
${ }^{11}$ Ibid., hal. 15

${ }^{12}$ Ibid., hal. 18.
} 
teknologi dalam segala aspek kehidupan. Bukti nyata yang dapat diamati adalah hampir seluruh individu dalam generasi tersebut memilih menggunakan ponsel pintar. Dengan menggunakan perangkat tersebut para milennials dapat menjadi individu yang lebih produktif dan efisien. Dari perangkat tersebut mereka mampu melakukan apapun dari sekadar berkirim pesan singkat, mengakses situs pendidikan, bertransaksi bisnis online, hingga memesan jasa transportasi online. Oleh karena itu, mereka mampu menciptakan berbagai peluang baru seiring dengan perkembangan teknologi yang kian mutakhir ${ }^{13}$. Generasi ini mempunyai karakteristik komunikasi yang terbuka, pengguna media sosial yang fanatik, kehidupannya sangat terpengaruh dengan perkembangan teknologi, serta lebih terbuka dengan pandangan politik dan ekonomi ${ }^{14}$. Sehingga, mereka terlihat sangat reaktif terhadap perubahan lingkungan yang terjadi di sekelilingnya.

\section{Jumlah dan Sebaran Generasi Milenial}

Pada tahun 2020, tahun dimulainya bonus demografi, generasi millennial

\footnotetext{
${ }^{13}$ Ibid., hal. 19.

${ }^{14}$ Badan Pusat Statistik, Statistik Gender Tematik: Profil Generasi Millenial, (Jakarta: KemenPPA, 2018), hal. 14.
}

berada pada rentang usia 20 tahun hingga 40 tahun $^{15}$. Usia tersebut adalah usia produktif yang akan menjadi tulang punggung perekonomian Indonesia. Tiga tahun menjelang era tersebut terjadi (2017), jumlah generasi milenial sudah dominan dibandingkan generasi lainnya. Menurut Susenas (2017), jumlah generasi milenial mencapai sekitar 88 juta jiwa atau 33,75 persen dari total penduduk Indonesia ${ }^{16}$.

\section{Generasi Milenial dan Teknologi}

Di tengah pesatnya perkembangan teknologi khususnya teknologi informasi dan komunikasi (TIK) inilah lahir dan tumbuh generasi yang dikenal dengan istilah Generasi $Y$ atau dikenal dengan Generasi Milenial ${ }^{17}$. Generasi milenial dianggap sebagai generasi yang lebih akrab dengan teknologi jika dibandingkan dengan generasi-generasi sebelumnya Salah satu perkembangan teknologi yang pesat adalah perkembangan piranti telekomunikasi nirkabel atau telepon seluler $(\mathrm{HP})^{18}$.

Telepon seluler sekarang tidak hanya digunakan untuk sarana komunikasi melalui suara saja tapi juga untuk

\footnotetext{
${ }^{15}$ Ibid., hal. 22.

${ }^{16}$ Ibid., hal. 22.

${ }^{17}$ Ibid., hal. 59.

${ }^{18}$ Ibid., hal. 60 .
} 
berbagai sarana lain seperti mengabadikan foto, mengecek dan mengirimkan email bahkan dapat melakukan transaksi perbankan. Dengan semakin "pintar" sebuah telepon seluler, maka tidaklah aneh bila sebuah telepon seluler menjadi bagian yang tidak terpisahkan oleh kehidupan manusia di era modern seperti sekarang ini.

\section{Cyber Counseling}

Dalam konsep yang sederhana konseling dapat dimaknai sebagai proses bantuan yang diberikan konselor kepada konseli untuk menyelesaikan masalah ${ }^{19}$. Prayitno, bahwa proses konseling bertujuan membantu konseli untuk dapat memahami diri dan lingkungannya, sehingga dapat membawa seseorang menuju kondisi yng membahagiakan, sejahtera, nyaman, dan berada pada kondisi kehidupan yang lebih efektif ${ }^{20}$. Konseling merupakan proses pemberian bantuan yang dilakukan melalui wawancara konseling oleh seorang ahli (disebut konselor) kepada individu yang sedang mengalami sesuatu masalah (disebut konseli) yang

\footnotetext{
${ }^{19}$ Pasmawati, H. Cyber Counseling Sebagai Metode Pengembangan Layanan Konseling Di Era Global. Jurnal Syi'ar. Vol. 16 No. 1. 2016, hal. 43.

${ }^{20}$ Prayitno dan Erman Amti. Dasar-dasar Bimbingan dan Konseling. (Jakarta: Renika Cipta, 2004), hal. 25 .
}

bermuara pada teratasinya masalah yang dihadapi konseli ${ }^{21}$. Cybercounseling secara umum dapat didefinisikan sebagai praktek konseling profesional yang terjadi ketika konseli dan konselor berada secara terpisah dan memanfaatkan media elektronik untuk berkomunikasi melalui internet ${ }^{22}$. Lebih lanjut dalam Wikipedia, cyber counseling dimaknai dalam jaringan atau keadaan saat sesuatu terhubung ke dalam suatu jaringan atau system (umumya internet atau ethernet). Jadi istilah konseling cyber counseling atau counseling online dapat dimaknai secara sederhana yaitu proses konseling yang dilakukan dengan alat bantu jaringan sebagai penghubung Konselor dengan konselinya ${ }^{23}$. Lebih lanjut cyber counseling adalah layanan terapi yang relatif baru. Konseling dikembangkan dengan menggunakan teknologi komunikasi dari yang paling sederhana menggunakan email, sesi dengan chat, sesi dengan telp pcto-pc sampai penggunaan dengan penggunaan webcam (video live sessions), yang secara

\footnotetext{
${ }^{21}$ Prayitno. Jenis Layanan dan Kegiatan Pendukung Konseling. (Padang: UNP Perss. 2012), hal. 136.

${ }^{22}$ Jerizal P \& Hanung S. Kajian Konseptual Layanan Cybercounseling. Jurnal Konselor. Vol. 6. No. 1. 2017, hal. 7.

${ }^{23}$ Pasmawati, H. Cyber Counseling Sebagai Metode Pengembangan Layanan Konseling Di Era Global. Jurnal Syi'ar. Vol. 16 No. 1. 2016, hal. 46.
} 
jelas menggunakan computer dan internet $^{24}$. Cyber Counseling adalah salah satu model konseling yang bersifat virtual atau konseling yang berlangsung melalui bantuan koneksi internet dimana konselor dan konseli tidak hadir secara fisik pada ruang dan waktu yang sama, dalam hal ini proses konseling berlangsung melalui internet dalam bentuk web-site,e-mail, facebook, video conference (yahoo massangger) dan ide inovatif lainnya ${ }^{25}$.

Berikut beberapa model cyber counseling yang telah di kembangkan dan disesuaikan dengan konseli yang merupakan generasi milenial, antara lain:

\section{Cyber Counseling berbasis E-mail}

Konseling merupakan suatu aktivitas proaktif-komprehensif untuk membantu individu mengatasi berbagai permasalahan kehidupan atau mengembangkan hidup. Konseling online adalah proses konseling yang dilakukan dengan menggunakan media komunikasi internet. Salah satu media yang digunakan adalah e-mail. Konseling

\footnotetext{
${ }^{24}$ Amani, Nasanin. Investigating The Nature, The Prevalence, And Effectiveness of Online Counseling, A Thesis, Department of Educational Psychology, Administration and Counseling, (California State university Long Beach, 2007)

${ }^{25}$ Pasmawati, H. Cyber Counseling Sebagai Metode Pengembangan Layanan Konseling Di Era Global. Jurnal Syi'ar. Vol. 16 No. 1. 2016, hal. 46.
}

melaluie-mail merupakan salah satu inovasi yang dikembangkan dari layanan konseling tatap muka, yang didalamnya konselor dan konseli dapat membahas mengenai masalah-masalah yang dihadapi konseli. Konseling e-mail tidak dikembangkan untuk menggantikan konseling tatap muka (face to face), tetapi menjadi salah satu cara inovatif dalam membantu konseli untuk memecahkan masalahnya ${ }^{26}$.

E-mail dipandang sebagai pilihan umum dan efektif untuk konseling online $^{27}$. Sussman menjelaskan e-mail sebagai cara paling mudah bagi konselor untuk membangun komunikasi online dengan konseli $^{28}$. E-mail merupakan bentuk komunikasi yang tersedia dan mudah antara individu-individu di kantor-kantor yang berdekatan dan juga dengan individu-individu di seluruh dunia. E-mail digunakan untuk konseling individual maupun kelompok dan memberikan manfaat besar dalam konseling karena keunggulannya dibandingkan dengan konseling tatapmuka ${ }^{29}$.

\footnotetext{
${ }^{26}$ Yosephpedhu, "Model konseptual cyber counseling berbasis e-Mail," Jurnal Psiko-Edukasi. Vol. 12. No. 1. 2014, hal. 78.

${ }^{27}$ Ibid., hal. 80.

${ }^{28}$ Ibid., hal. 81.

${ }^{29}$ Ibid, hal. 80 .
} 
Murphy dan Mitchell (dalam telepon. Oleh karena esensi konseling McLeod, 2006) $)^{30}$ memaparkan beberapa berbasis e-mail terletak pada keunggulan konseling e-mail antara lain: menulis,maka respon yang diberikan (a) terdapat catatan permanen seluruh kontak konseling yang berguna bagi konseli, konselor dan supervisor; (b) mengetik merupakan cara efektif untuk menginternalisasikan masalah; (c)mengetik membantu seseorang untuk merefleksikan pengalaman mereka; (d) ketidakseimbangan

kekuatan berkurang-internet merupakan medium yang egalitarian; (e) konseli dapat mengekspresikan perasaan mereka saat ini juga, konseli dapat menulis pesan $e^{-}$ mail saat berada di tengah depresi daripada menunggu datangnya sesi konseling berikutnya. Konseling e-mail merupakan proses konseling yang di dalamnya terdapat kegiatan menulis dan membaca $^{31}$. Menurut McLeod (2006) ${ }^{32}$ layanan konseling e-mail telah lama digunakan sebagai biblioterapi dan menulis terbimbing. Hasil penelitian mendukung bahwa biblio terapi memfasilitasi wawasan dan perubahan diri konseli secara efektif, khususnya apabila dikombinasikan dengan konseling tatap muka dan kontak

\footnotetext{
${ }^{30}$ Ibid, hal. 81.

${ }^{31}$ Ibid, hal. 81.

${ }^{32}$ Ibid, hal. 81.
} konselor bergantung pada informasi yang diberikan. Konseli pun tidak perlu mengirimkan seluruh cerita mengenai masalahnya, namun dapat dengan bebas memilih informasi yang dirasa perlu untuk disampaikan kepada konselor melalui e-mail.

$$
\text { Mallen,Vogel,\& Rochlen }(2005)^{33}
$$

dan Jones menjelaskan pentingnya etika untuk melakukan konseling online, khususnya berkaitan dengan aspek kerahasiaan dan privasi konseli yang harus dijaga secara mutlak. Gibson dan Mitchell (2011) $)^{34}$ mengutip National Board for Certified Counselors and Affiliates yang memaparkan soal kerahasiaan di dalam konseling internet sebagai berikut: (a) Konselor memberikan informasi kepada konseli mengenai metode penyandian yang digunakan untuk membantu menjamin keamanan komunikasi konseli atau konselor/supervisor. Jika tidak menggunakan metode penyandian, konseli harus diberitahu akan potensi bahaya ketidakamanan komunikasi pada internet berupa pemantauan transmisi

\footnotetext{
${ }^{33}$ Yosephpedhu, "Model konseptual cyber counseling berbasis e-Mail”. Jurnal Psiko-Edukasi. Vol. 12. No. 1. 2014, hal. 81. ${ }^{34}$ Ibid, hal. 81.
} 
dan/atau catatan sesi konseling internet di luar izin; (b) Konselor harus memberikan informasi kepada konseli jika, bagaimana, dan berapa lama data sesi yang akan disimpan yang dapat berupa e-mail konselor atau konseli, hasil tes, rekaman video atau audio, catatan sesi, dan komunikasi konselor atausupervisor; (c) Konselor mengikuti prosedur yang tepat dalam pelepasan informasi untuk membagi informasi mengenai konseli dengan sumber elektronik lainnya. Mengingat relative mudahnya meneruskan pesan email ke sumber rujukan formal dan non-formal, konselor harus berusaha menjamin kerahasiaan hubungan konseling internet.

Layanan konseling berbasis e-mail juga memiliki kelemahan yakni munculnya kesulitan bagi konselor dan konseli yang belum memahami teknologi komputer dengan baik, kesulitan dalam memahami emosi yang muncul dari kedua belah pihak terutama konseli, konselor tidak dapat memastikan keseriusan konseli, ketersediaan perangkat komputer yang masih mahal yang tidak bisa dijangkau oleh semua individu, keterbatasan informasi yang diterima, terjadinya komunikasi satu arah, klasifikasi dan eksplorasi tidak segera dilakukan sehingga dapat terjadi kesalahpahaman; permasalahan yang dihadapi konseli beraneka ragam dalam emosi sehingga konselor kadang kadang mengabaikan segi-segi yang penting dalam proses konseling; proses konseling dapat saja terputus dan bahkan tidak dapat terselenggara dengan matinya listrik, koneksi terganggu, atau rusaknya perangkat yang digunakan ${ }^{35}$.

\section{Cyber Counseling berbasis chat}

\section{Asynchronous}

Cybercounseling Chat-Asynchonous seperti email dan text chat, orang tidak harus duduk didepan komputer yang tersambung ke dalam jaringan (online). Biasanya ini berarti ada peregangan kerangka waktu di mana interaksi terjadi, anda memiliki jam, hari, atau bahkan minggu untuk menanggapi pesan tersebut ${ }^{36}$. Cyberspace menciptakan ruang sementara yang fleksibel, waktu interaktif bersama konseli dapat dilakukan dengan singkat, sesuai

\footnotetext{
${ }^{35}$ Yosephpedhu, "Model konseptual cyber counseling berbasis e-Mail”. Jurnal Psiko-Edukasi. Vol. 12. No. 1. 2014, hal. 82.

${ }^{36}$ Prasetya, "Model Cyber counseling : Telaah Konseling Individu Online Chat-Asynchronous Berbasis Aplikasi Android," (dalam Prosiding Seminar Bimbingan dan Konseling, Vol. 1, No. 1, 2017 Universitas Ahmad Dahlan), hal. 32 .
} 
kebutuhan. Kesempatan untuk memberikan pelayanan konseling. Asas mengirim pesan ke konselor dapat kerahasian inilah yang menjadi prioritas dilakukan setiap saat dan menciptakan dalam proses konseling individu perasaan nyaman bahwa konselor selalu berbasis cyber yang data-datanya akan ada, selalu hadir, yang memudahkan disimpan secara rapi dalam sebuah jarak pemisahan dan memungkinkan sistem, dan sewaktu-waktu dapat konseli untuk mengartikulasikan pikiran dan perasaan mereka dengan segera kepada konselor, daripada harus menunggu pada pertemuan konseling berikutnya $^{37}$.

Cyber counseling Chat-Asynchonous berbasis android dalam hal ini, menekankan pada asas kerahasiaan dari konselinya dan memiliki penyimpanan data yang dapat di print-out sebagai laporan kegiatan pertanggungjawaban kinerja terhadap atasan ${ }^{38}$. Kerahasiaan ini dimaksudkan agar permasalah konseli tidak boleh sampai diketahui oleh orang lain dan benar-benar terjaga kerahasiannya. Menurut Corey (2009: $35)^{39}$, kerahasiaan merupakan pusat pengembangan kepercayaan dan produktifitas hubungan konseli dengan konselor yang merupakan masalah etis dan sekaligus legal. Adapun menurut Sukardi (2008: 46) ${ }^{40}$, asas kerahasiaan merupakan asas kunci dalam

${ }^{37}$ Ibid., hal. 33.

${ }^{38}$ Ibid., hal. 34-35.

${ }^{39}$ Ibid., hal. 35.

${ }^{40}$ Ibid., hal. 35.

digunakan sebagai bukti pelaksanaan konseling oleh konselor.

Proses Cyber counseling ChatAsynchonous berbasis android dapat dikelompokkan dalam pelayanan responsif. Menurut ABKIN (2008: 209) ${ }^{41}$, pelayanan responsif adalah pemberian bantuan kepada konseli yang menghadapi kebutuhan dan masalah yang memerlukan pertolongan dengan segera, sebab jika tidak segera dibantu dapat menimbulkan gangguan dalam proses pencapaian tugas-tugas perkembangannya.

\section{Cyber Counseling Berbasis Teks Menggunakan Riliv Aplikasi Android}

Telah dibuat aplikasi Appstore dimana proses konseling dilaksanakan online melalui aplikasi Riliv. Riliv merupakan social network yang menghubungkan klien dengan konselor secara online $e^{42}$. Riliv merupakan sebuah

\footnotetext{
${ }^{41}$ Ibid., hal. 35.

${ }^{42}$ F. Yuni A, Made Darmawan R, Eli Prasetyo, Pemanfaatan Teknologi Bagi Generasi Millenial : Konseling Berbasis Teks Menggunakan Riliv-Aplikasi Android. Jurnal Experientia. Vol 6, No. 1. 2018, hal. 47.
} 
social network yang menghubungkan setiap orang yang memiliki permasalahan pribadi untuk menyelesaikannya melalui konseling online berbasis teks. Aplikasi ini menghubungkan seorang psikolog atau ilmuwan psikologi dengan user sebagai klien untuk proses konseling berbasis teks. Riliv dirancang dengan konsep konsultasi one on one oleh psikolog profesional secara anonim. Segala bantuan psikologi melalui konseling dapat tetap dilaksanakan secara profesional dan memenuhi kaidah proses konseling pada dasarnya dapat diterapkan melalui aplikasi android di Riliv ${ }^{43}$.

\section{Cyber Counseling Berbasis Facebook}

Tujuan pengembangan model cyber counseling berbantuan facebook ini sebagai wadah individu yang cenderung memililiki keterbatasan jarak, waktu, dan seringkali merasa tidak nyaman untuk melakukan pertemuan secara langsung bertatap muka dengan seseorang ahli ${ }^{44}$. Shaw\&Shaw $(2006)^{45}$

\footnotetext{
${ }^{43}$ Ibid., hal. 49.

${ }^{44}$ Arifah P, Pengembangan Model Cyber Counseling Berbantuan Facebook Untuk Meningkatkan Efektivitas Layanan Informasi Karier Di Sma Negeri 1 Semarang. Prosiding Seminar Nasional Strategi Pelayanan Bimbingan Dan Konseling Di Era Disrupsi Semarang, 21 Juli 2018, hal. 23.

${ }^{45}$ Ibid., hal. 23.
}

mengatakan bahwa cyber counseling sangat cocok bila diberikan pada klien yang “....(c) yang tidak ingin melakukan konseling face to face (d) lebih suka menulis dari pada berbicara" Karena itulah kelompok pada penelitian ini merupakan sub populasi yang bisa menerima dan memiliki ketertarikan untuk menggunakan bentuk layanan $e^{-}$ counseling. Landasan cyber counseling berbantuan facebook ini digunakan sebagai bentuk pengembangan untuk memperkuat pencapaian manfaat layanan bimbingan dan konseling ${ }^{46}$.

\section{Penutup}

Penggunaan teknologi dalam konseling telah tumbuh sangat cepat. Apa yang semula hanya janji, kini telah menjadi kenyataan, dan teknologi telah memberikan dampak yang kuat pada hampir semua aspek kehidupan, termasuk pendidikan.

Bagi seorang konselor sangatlah penting untuk memahami cyber counseling karena seiring dengan perkembangan teknologi modern, penerapan teknologi non internet kemungkinan sudah merata tetapi teknologi yang berbasis internet

\footnotetext{
${ }^{46}$ Ibid., 24.
} 
diperkirakan hanya beberapa sekolah dan kebiasaan berada diperkotaan. Sehingga kemungkinan penerapan teknologi khususnya diperuntukkan bagi layanan bimbingan dan konseling masih kecil karena selain dari segi biaya, kompetensi konselor pun menjadi tolak ukur. Kebanyakan konselor kurang memiliki keterampilan dalam mengelola aplikasi-aplikasi teknologi komputer berbasis internet, kecuali jika konselor tersebut mau meluangkan waktunya untuk belajar atau mempunyai teman yang ahli dalam bidang teknologi sehingga kerjasama tersebut bisa mempermudahkan dan memperluas pengetahuan konselor.

\section{Daftar Pustaka}

Amani, Nasanin. Investigating The Nature, The Prevalence, And Effectiveness of Online Counseling, A Thesis, Department of Educational Psychology, Administration and Counseling, (California State university Long Beach, 2007)

Arifah P. "Pengembangan Model Cyber Counseling Berbantuan Facebook Untuk Meningkatkan Efektivitas Layanan Informasi Karier Di Sma Negeri 1 Semarang". Prosiding
Seminar Nasional Strategi Pelayanan Bimbingan Dan Konseling Di Era Disrupsi Semarang, 21 Juli 2018 .

Badan Pusat Statistic. 2018. "Statistik Gender Tematik: Profil Generasi Millenial". Jakarta. Kementerian Pemberdayaan Perempuan dan Perlindungan Anak.

F. Yuni A, M Darmawan R, Eli P. 2018. "Pemanfaatan Teknologi Bagi Generasi Millenial : Konseling Berbasis Teks Menggunakan RilivAplikasi Android”. Jurnal Experientia (Vol 6, No 1 Thn. 2018)

Pasmawati H. "Cyber Counseling Sebagai Metode Pengembangan Layanan Konseling Di Era Global" . Jurnal Syi'ar (Vol. 16 No. 12016 )

Ifdil, 2011. "Penyelenggaraan Layanan Konseling Online Sebagai Salah Satu Bentuk Pelayanan EKonseling". Seminar Internasional Bimbingan dan Konseling Universitas Pendidikan Indonesia $29 \mathrm{~s} / \mathrm{d} \quad 30$ Oktober 2011

Jerizal P \& Hanung S. 2017. “Kajian Konseptual Layanan Cyber counseling". Jurnal Konselor (Volume 6 Number 1 2017)

Nakhma'ussolikhah."Studi Tentang Penggunaan Cyber counseling 
al-Tazkiah, Volume 8 No. 1, Juni 2019

Untuk Layanan Konseling Prayitno dan Erman A. 2004 Dasar-dasar Individual Bersama Mahasiswa Bimbingan dan Konseling. Jakarta: Program Studi Bimbingan Dan Renika Cipta

Konseling Unu Cirebon" Oasis : Ramidi \& Hariyanto. "Generalisasi Jurnal Ilmiah Kajian Islam (Vol 2. No Bimbingan Konseling Pribadi Dan 1 2017)

Nur Cahyo HW. "Bimbingan Konseling Online" Jurnal Ilmu Dakwah (Vol. 36 No 2 2016) Sosial Untuk Remaja Di Era Milenial" Jurnal Al Tazkiah, Vol 7, No. 2, 2018)

Sutijono \& Dimas A, Miftah F."Cyber Counseling Di Era Generasi Telaah Konseling Individu Online Chat-Asynchronous Berbasis Aplikasi Android," dalam Prosiding Seminar Bimbingan dan Konseling, Yosephpedhu, "Model konseptual Cyber Vol. 1, No. 1, 2017 Universitas Ahmad Dahlan counseling berbasis e-Mail," Jurnal Psiko-Edukasi (Vol. 12 No 1 Thn

Prayitno. 2012. Jenis Layanan dan 2014)

Kegiatan Pendukung Konseling. (Padang, UNP. Perss. 